\title{
MATHEMATICAL INSTRUCTION IN FRANCE.
}

BY PROFESSOR JAMES PIERPONT.

\section{Introduction.}

The following paper falls into two parts. In the first part, I propose to give an account of the way France is educating those of its youth who wish to become mathematicians, to indicate rapidly what positions a young man of talent may hope to reach, how he attains them, and what his duties are in the various stages of his career. In the second part, I wish to call attention to the advantages which Americans can enjoy in studying mathematics in France, particularly in Paris.

An article of this nature seemed to me to be not only of general interest, but also of considerable importance, and for this reason. We American professors discharge a double office : we are not only professors, in that we investigate and teach ; but we are also administrative officers. The direction and form that our secondary and higher instruction takes depends in a large measure upon us. It is therefore advisable not only to know what England and Germany have to teach us on this subject, but also to inform ourselves of the system of mathematical instruction current in France. At the present moment our graduate schools are in a period of formation. What is plastic and easy to mould now will fifty years hence be difficult or quite impossible to change. It is patent to every one that our new university life is being moulded largely after German ideals. Ninetynine per cent. of our younger men have received their inspiration in Germany; it is only natural that we should have German methods before our eyes in shaping the course our graduate instruction shall take. It is at first sight indeed remarkable how ignorant we are of the scheme of mathematical instruction that prevails in France. The land that has produced Cauchy, Poncelet, Laplace, Monge, Hermite is quite ignored by us. How many of us know anything of the famous Classe de mathématiques spéciales, or of the rôle the École Normale plays in forming the elite of French mathematicians. It is a question in my mind whether it is wise for us to imitate so freely German methods, and be so largely dominated by the German way of looking at things. America is not a New Germany. To counteract this excessive German influence, it seems desirable that we should have among us a respectable minority who have spent con- 
siderable time under French influences. It is well, so it seems to me, that a part of our gifted youth should havereceived their inspiration from men like Poincaré and Picard, Darboux and Koenigs, Painlevé, Borel and Hadamard.

The present moment is very auspicious for Americans who wish to study mathematics in France. The French are beginning to be very much awake to the desirability of not remaining longer isolated in this particular. They are beginning to realize that the thousands of Americans who study in Germany, who are there hospitably received, and after one or more happy and prosperous years return to America, become centers of propaganda for German ideas and help to establish between the two countries relations of no mean value, for which France has no equivalent. Certain it is that the American student of mathematics will be well received and given most precious opportunities of study. But of this more in detail in the second part of this paper.

\section{I.}

\section{General Remarks on French Instruction.}

I begin by observing that practically all instruction given in France is given by the State ; for one and the same grade it is therefore sensibly uniform. Remark also that France has made gigantic efforts in the last thirty years to improve instruction in every way. The State and the larger cities have spent prodigious sums to this end. New buildings have been erected in multitude, chairs endowed, laboratories equipped, libraries provided, and salaries improved. The number of scholarships offered to encourage effort, particularly to enable young men of exceptional talent but slender means to go on with their studies, indicates strikingly how eager the French Republic is to avail itself of talent wherever found. So far as we are concerned, the instruction falls under two heads ; secondary, given in the lycées ; superior, given in the Sorbonne, the Collège de France, the École Normale, and the École Polytechnique. Consider first the lycées. As the sexes are divided from the start we can consider here only those for boys.

Elementary Mathematical Instruction. The Lycḱes.

The lycées are large schools scattered throughout all the cities of France. They take the children of parents in comfortable circumstances as early as five years of age, and lead them to the baccalaureat when they are generally 17 or 18 
years old. The élèves are of three kinds : $1^{\circ}$ externes, who like the children of our grammar and high schools live at home and go to school only to recite; $2^{\circ}$ internes or pensionnaires, who live entirely at the lycée, as in our great preparatory schools, Exeter and Andover; $3^{\circ}$ demi-pensionaires, who pass the whole day at the lycée and the night at home. As internes children are not received before 6 years of age. Many families do not send their boys to a lycée till they are 10 or 12 years old, preferring to educate them more privately till then. The expenses are fixed by the State and vary from one city to another. For example, in Lyons, Bordeaux, Marseilles I find :

for externes, from 70 to 300 francs per year ;

for demi-pensionnaires, from 375 to 625 francs per year;

for pensionnaires, from 650 to 950 francs per year.

Here the first sum in each case corresponds to the lowest class and the last sum to the highest class. In Paris the prices are a little higher, in small towns a little less. The boys wear a peculiar dress or uniform, whose cut is partly regulated by the State. Until about the age of 11 the instruction is the same for all élèves. At this point a bifurcation takes place, into enseignement classique and enseignement moderne. The latter is without Latin or Greek. As the number of careers open to youths who have had Latin and Greek is much greater, about 80 per cent. of the parents in their uncertainty what talents their boys are destined to develop choose the classical course. It is well, however, to remark that today in France neither Latin nor Greek is necessary to obtain a doctor's degree in mathematics or the natural sciences. For our educators in America this is surely a significant fact. Harvard is, I believe, the only prominent American university which takes a stand approaching this. It is to be regretted that the exigencies of the French scheme of instruction force a choice when the children are at so tender an age. A delay of a few years would permit many an uncertain parent to decide for the modern course.

I wish to give now some details on the instruction given at the'lycées. Perhaps the most flagrant source of weakness in our American system of higher education lies in our preparatory and high schools. We mathematicians have only to think of the entrance papers in mathematics to see the truth of this. Certainly at Yale we lose a good part of the Freshmen year training our men into form. It is therefore important for us to compare the training French boys get in mathematics with that which our boys receive. 
In the first place I remark that after the age of 7 or 8 French boys are taught by men. These men have all studied at the university and have passed the examen de licence. For the higher classes the instructors have passed the extremely severe examen d'agrégation in the subjects they propose to teach. It is too humiliating for us to inquire here what our teachers of like grades have done to prepare themselves for their duties. That precious years are often lost to our youth by their inferior instruction is apparent to all. Add at once, however, that a brighter future is in store for us. As the country grows older our educators must see that men teachers take many of the places now occupied by women. On the other hand, the number of students at our universities who are following graduate courses is so large that the greater part of these must be content with positions in high schools and the better preparatory institutions. It is thus to be expected that the quality of the candidates for admission to our freshman classes will improve steadily.

In the limits of this article it is impossible to follow every turn of the instructions at the lycées. For this reason, I can speak only of the classical course. Aside from lacking Latin and Greek, the modern course differs from it but little. The bifurcation begins at the sixth class; the first class is called the classe de rhétorique. Here is a program for the week :

\begin{tabular}{|c|c|c|c|c|c|c|c|c|c|c|c|c|c|c|}
\hline$\frac{\dot{0}}{\stackrel{0}{0}}$ & $\underset{80}{\dot{\Phi}}$ & 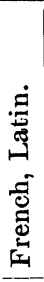 & 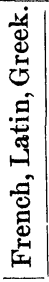 & 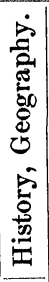 & $\begin{array}{l}\dot{0} \\
0 \\
\dot{0} \\
\dot{0}\end{array}$ & 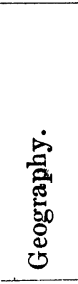 & 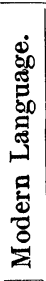 & $\begin{array}{l}\dot{8} \\
\frac{8}{8} \\
\stackrel{8}{0}\end{array}$ & 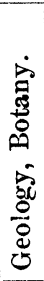 & 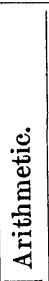 & 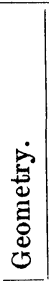 & 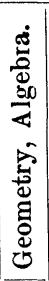 & 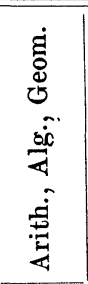 & 㶾 \\
\hline $\mathrm{V}$ & 11 & 13 & $\ldots$ & 2 & .. & & 3 & 1 & 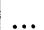 & 1 & $\ldots$ & $\ldots$ & & 20 \\
\hline V & 12 & $\ldots$ & 13 & 2 & $\ldots$ & & 3 & $\ldots$ & 1 & 1 & $\ldots$ & $\ldots$ & & 2 \\
\hline IV & 13 & $\ldots$ & 13 & $\ldots$ & 2 & 1 & 2 & $\ldots$ & $\ldots$ & $\ldots$ & 2 & $\ldots$ & & 20 \\
\hline III & 14 & $\ldots$ & 12 & $\ldots$ & 2 & 1 & 2 & $\ldots$ & $\ldots$ & $\ldots$ & $\ldots$ & $\ldots$ & 3 & 20 \\
\hline II & 15 & $\ldots$ & 12 & $\ldots$ & 2 & 1 & $\tilde{2}$ & $\ldots$ & $\ldots$ & $\ldots$ & $\ldots$ & 3 & & 20 \\
\hline Rhet. & 16 & $\ldots$ & 12 & $\ldots$ & 2 & $1-2$ & 3 & & & & & $\ldots$ & $2-1$ & 20 \\
\hline
\end{tabular}

In addition to these subjects, the élève has from $1 \frac{1}{2}$ to 2 hours per week in drawing, starting with Class VI. The first feature that strikes us in this scheme is the number of hours the French boy has in class work. Next we observe that he has 15 to 16 hours of class work a week in lan- 
guages and only 1, 2, or 3 in mathematics. Also we note that his studies in arithmetic, algebra, and geometry are constantly intermingled, and not kept apart as with us. To us it is rather surprising that so little time is given to mathematics. French parents complain that their boys forget one week what they learned the week before. We remark also that their native tongue is from the start placed on an equality with the classical languages. The modern language is usually German, since this is required at the entrance examinations of many of the government schools, in particular the Ecole Polytechnique.

Let us see what the French boy learns in the classe de rhétorique, at which time he is 16 years old.

Latin. Selections from Cicero, Livy, Seneca, Tacitus, Horace.

Greek. Selections from Thucydides, Xenophon, Plato, Demosthenes, Homer, Aristotle, Aristophanes.

French. Selections from authors ranging from the time of Montaigne to Hugo, a study of the principal features of the literature at each period, the theatre, the moralists, the eloquence of the church, letters and memoirs, the philosophers and savants, etc.

German. Selections from Lessing, Goethe, and Schiller.

History. History of Europe, 1610-1789.

Geography. Detailed study of France from the geological, economic, and sociological standpoints.

Arithmetic. Properties of integers, fractions, decimals, square roots, etc.

Algebra. Simultaneous linear equations, quadratic equations.

Geometry. Solid geometry.

Astronomy. Elements.

I wish to note here that arithmetic is taught as a science, not as an art. I do not believe our boys ever have the elementary processes of arithmetic : long division, extraction of roots, etc., demonstrated to them till they reach the graduate school of the university. A peculiarity of great interest is this: mathematics is taught by lectures from Class III., $i$. e., when the élève is only 14 years old, onward. Each lycée has a library which the élèves are encouraged to consult. But it is from his note books rather than from a textbook that he learns his mathematics. To us this seems remarkable indeed. Even in most of our colleges, to say nothing of high schools, the student learns his lessons from his book. To my mind, our custom of teaching mathematics from textbooks to boys of 18 years or more is pernicious. 
It is ridiculous to say that our students are too immature to take proper notes at this age. I have inspected a number of note books of boys much younger than this in Paris lycées, and was pleased to find them neatly and fully taken. In this respect Harvard is probably in advance of other universities.

We have now reached a new period in the school life of a French boy. The classe de rhétorique finished, he passes the first part of his baccalauréat. A peculiar feature of these examinations is that they are not held at the lycée, nor under the charge of its professors, but at the university in whose district the particular lycée is situated. Whether the élève has the intention of attending a university is quite immaterial. The degree of baccalauréat is a State diploma. A considerable number of government positions can be occupied by no one who has not this diploma. The State sees fit to entrust the charge of so important examinations to a class of men wholly independent of the lycées, namely, university professors. This is, no doubt, a relic of the days of the first Napoleon, when the lycées formed an integral part of that monstrous institution, l'Université de France. 'The examinations are written and oral ; only those who pass the written examination are admitted to the oral. In 1897, 16,625 of these examinations were held in the classical course, and 5,691 in the modern. Of the first only 6,269 were successful, of the second 2,328. We observe that less than one-half were successful in each category, a fact which shows they are no playful affairs. On returning to the lycée, to prepare for the second part of the baccalauréat, the lycéen has a choice of two courses, classe de philosophie and classe de mathématiques élémentaires. Those who have little taste for mathematics will choose the first, the rest will choose the second. We are interested only in these last. The boys who enter this class have already a pronounced taste for mathematics and the natural sciences. A considerable part of them will later try to enter the great government schools as the École Polytechnique, the École Normale, the École Centrale, École St. Cyr, École Navale, etc. For all these the requirements in mathematics are severe. We shall not be surprised then to see, in the scheme of studies, mathematics spring from two or three hours a week to ten, while Latin and Greek disappear altogether and modern languages have one hour. Here is a scheme of studies :

Mathematics, 10 hours per week ; physics and chemistry, 6 hours; anatomy and physiology of animals and plants, 1 . hour ; philosophy, 2 hours ; modern history, 3 hours ; French or German, 1 hour. 
The total is 23 hours of class-room work for a boy of 17 . When we recall that our young men in college from 18 to 22 years of age have but 15 hours, we are compelled to.reflect which system errs ; is one in excess, or the other in default? After visiting leading lycées in Paris, I can testify that the élèves seemed as buoyant in spirit and healthy in body as our own. The excess, if it be excess, seems to make them only more boisterous in their play hours.

I mention for lack of space only what is taught in mathematics: arithmetic, algebra, plane and solid geometry, conic sections by elementary geometry, plane trigonometry, descriptive geometry, mechanics, theory of simple mechanisms, cosmography. We observe that arithmetic is still taught. The reason for this is that, like geometry, it is taught as a science and not as a compendium of rules, to be learned by heart and practised mechanically. The presence of descriptive geometry is explained by the fact that the government schools just alluded to, being technical, require it for entrance.

At the end of this year, the second part of the baccalaureat is taken. If successful, the élève receives a diploma from the minister of public instruction called the baccalaureat de l'enseignement secondaire classique. Those who have followed the modern course receive a similar diploma with the word classique replaced by moderne. Élèves of the enseignement moderne after passing the first part of the baccalaureat enter this class of mathématiques élémentaires which $I$ have just described, if they propose to enter the government schools mentioned above.

We have reached now a point where another peculiarity of French instruction meets us. Our young laureat who has a taste for mathematical studies does not now enter the university, as he has a right to and as his German or American comrade does. Instead, he returns to his old lycée or enters a large Paris lycée, like St. Louis or Louis-le-Grand, which pays particular attention to fitting its pupils to succeed in the highly competitive examination of the great and celebrated government schools. For us only the École Normale and the École Polytechnique are of interest. The difficulty of entering these is shown by the following figures. In $1897,1,023$ candidates presented themselves at the École Polytechnique ; 224, or 22 per cent., were admittd. At the École Normale the number of candidates in science was 260 ; of these 13 , or 5 per cent., were received. The number that will be received is fixed in advance and is limited by the capacity of the school. A student usually tries twice or 
thrice, before he succeeds or concludes that he had better give it up. For the mast persevering, however, there exists a limit. At the Ecole Polytechnique no élève who is 21 years or more of age will be received; at the École Normale, the age limit is 24 years. What these schools are and what makes them so tempting I shall state later. Return now to our candidate. He re-enters, as stated, the lycée, passing into the classe supérieure de mathématiques élémentaires. This class prepares him for the arduous work of the classe de mathématiques spéciales. His studies in this preparatory class are largely the same as in the classe de mathématiques élémentaires, only more advanced. They are : arithmetic, plane and solid geometry, descriptive geometry, algebra, plane analytic geometry, physics and chemistry. In passing, observe that from this point on to the agrégation or doctorate the studies of the French boy pursuing mathematics are in the highest degree technical and special. History, literature, philosophy, logic, psychology, in short the humanities have now disappeared from his program of studies never to reappear except 4 hours of literature in the following class and enough German to pass the entrance examinations at the École Normale or Polytechnique.

Pass now to the famous classe de mathématiques spéciales. The amount of instruction in mathematics given in this class is I believe without parallel in any country in the world. When I looked over for the first time the field covered by these boys of 18 or 19, I was amazed. It did not seem possible to me that they could survive the treatment. And yet they show no signs of fatigue, as far as I could see. Here is the scheme of their studies: mathematics, 12 hours per week ; physics, 4 hours ; chemistry, 2 hours; literature, 4 hours; German, 2 hours; design, 4 hours ; épure, 4 hours. The course is fitted exactly for the requirements of admission at the Écoles Normale and Polytechnique. The topics examined on at both these schools are the same, but the examination at the École Normale is the more searching. The following works will indicate roughly the scope of the mathematical lectures.

Niewenglowski : Cours d'algèbre, Vol. I., pp. 382 ; Vol. II., pp. 508. By the same author, Cours de géométrie analytique, I., p. 483 ; II., p. 292 ; III., p. 569. For trigonometry I mention the work by Vaquant (1 vol., pp. 401 ), and for descriptive geometry that of Jarvary (Vol. I., pp. 265 ; Vol. II., pp. 702). These works are a little fuller than the actual courses; but even when we have made the necessary allowance, the amount that remains 
seems overwhelming to us. In passing let me add that a very good idea of the courses given in the classe supérieure de mathématiques élémentaires can be formed by perusing the series of textbooks edited by Darboux, namely, the Cours complet de mathématiques. An exception is the arithmétique by Tannery. For this the Traité d'arithmétique by $\mathbf{E}$. Humbert is nearer what is taught.

I have been present at exercises in these two classes at St. Louis and Louis-le-Grand, and although I came at an unexpected moment, the exhibition of dexterity in attacking difficult problems and of accurately and rapidly performing long analytical calculations is nowhere even approached, I believe, in America. I express the sincere wish that our professors may attend these exercises. They will then realize how much we have to learn from the French lycées.

After a year spent in the classe de mathématiques spéciales, those fitting themselves to follow the career of mathematics present themselves at both the Ecole Normale and the École Polytechnique. The élite, $i$. e., 2 to 5 per cent. of them, succeed at one or the other of these places at the first trial; the rest return to the lycée and repeat the classe de mathématiques spéciales. They go over the same ground, but much that they understood before imperfectly now becomes clearer. They present themselves at the end of this year again. In the second trial about 25 per cent. succeed. It is now a fact that less than half of those who enter the classe de mathématiques spéciales succeed even after a third trial. The rest either go to the Sorbonne as étudiants libres or give up their aspirations to become mathematicians and try to enter a government school where the examinations in mathematics are less severe.

This question arises : if only from 2 to 5 per cent. can succeed in the first trial and the rest have to return and go over the same ground again, why is it not more rational to divide this prodigious amount of matter crowded into one year and spread it over two ? The answer seems to be this : The government is eager to pick its servants from the best of the nation's youth. This is done by these highly competitive examinations. At the same time if an élève is sufficiently gifted to succeed in one year of mathématiques spéciales, it is to his own and the government's interest to push him forward in his high career. Almost all the young mathematicians of today who are adding new luster to France's fair renown in mathematics succeeded after a single year in this remarkable class. 


\section{Higher Mathematical Instruction.}

With this brief sketch of secondary instruction in mathematics, let us turn to the enseignement superieure. This takes us to the Sorbonne, the Collège de France, the École Normale, and the École Polytechnique.

\section{The Sorbonne.}

We describe in a few words the relation between the University of Paris and the Sorbonne, a point not clear to all. Before the great upheaval of 1789 there were scattered about in France various universities whose foundation and government were similar to those of other European universities. These universities were all suppressed in 1793. Under Napoleon they were again revived ; not, however, as separate corporate bodies. All the universities, the little collèges, and the lycées were united into one great body, l' Université de France. This reduced the universities to an association of faculties with no local self-government worthy of the name. Within recent years the desire became ever stronger to return to the old régime; to give the universities each a separate existence, a budget, a power of local administration ; they were however to remain, as elsewhere, more or less dependent upon the ministère de l'instruction publique. The change eventually took place in 1896. The Université de Paris to-day consists of 5 faculties ; Faculté des sciences, des lettres, de droit, de médecine, and de théologie. The faculties of science and letters have their offices, lecture rooms, laboratories, etc., in the building called the Sorbonne. Here also are the university library and the central offices of university administration. In passing we remark that these two faculties constitute what is called in Germany the philosophische Facultät.

The Sorbonne, as it now stands, is a gigantic and magnificent structure built to replace the old Sorbonne built by Richelieu. It was begun in 1885 and is now all but complete. Very picturesquely it encloses the old church of the Sorbonne also built by Richelieu and containing his magnificent tomb.

Turn now to the mathematical department. Instruction is given by $1^{\circ}$ professeurs who occupy chairs each covering a definite part of what is called in France the sciences mathématiques; $2^{\circ}$ professeurs adjoints; $3^{\circ}$ chargés du cours; $4^{\circ}$ maîtres de conférences. There are no Privat-docenten in France. All instructors are appointed for life except in cases which are obviously exceptional or temporary, and receive salaries 
according to a fixed scheme of advancement. There is no competition among the universities, as in Germany which allows some professors to receive twice the salary they otherwise would or to enjoy exceptional privileges. There are nine chairs which interest us ; I add their present occupants.

$1^{\circ}$ Géométrie supérieure; Darboux.

$2^{\circ}$ Analyse supérieure; Picard.

$3^{\circ}$ Calcul différentiel et intégral ; Goursat.

$4^{\circ}$ Mécanique rationelle; Appell.

$5^{\circ}$ Mécanique céleste; Poincaré.

$6^{\circ}$ Astronomie; Wolf.

$7^{\circ}$ Mécanique physique et expérimentale; Koenigs.

$8^{\circ}$ Physique mathématique; Boussinesq.

$9^{\circ}$ Physique générale ( 2 chairs) ; Lippmann, Bouty.

In mathematics the only professeur adjoint is M. Puiseux, while the chargés du cours and maîtres de conférences are Raffy, Andoyer, Blutel, and Hadamard. Unlike the German universities, where instruction in these subjects is free from the taint of examinations, the universities of France are required to spend a large part of their efforts to fit their students to pass two State examinations, the licence, and the agrégation. These examinations, particularly the latter, require the student to have an elaborate knowledge of certain subjects and it is the duty of the university to see that students of a certain calibre of mind and degree of assiduity are prepared and drilled to pass them. For this reason the courses $3^{\circ}, 4^{\circ}, 6^{\circ}, 7^{\circ}, 9^{\circ}$ are the same each year. On the contrary the courses by Darboux, Picard, Poincaré, and Boussinesq are variable. The wide range and the elegance of the courses given by Darboux, Picard, and Poincaré are known the world over through their published reproductions.

The first peculiarity that meets us is that half the courses are repeated each year almost without change. The next feature that attracts our attention is that no professor gives more than one course of lectures, $i$. e., two lectures a week; while Darboux, Picard, Lippmann, and Bouty lecture but one semester, or less than four months a year. From this it results that the number of courses the university offers the student during an abode of two or three years is small in comparison with a large German university where each professor gives usually two or three courses a semester which often run through a cyclus of two or three years. We next remark that the maîtres de conférences do not lecture on subjects which interest them, as does the privat docent in Germany, thus swelling the number of courses a German university offers, but that they employ their efforts to drill 
the students and elucidate more fully the lectures of the professor. Thus during the present semester Hadamard did this for Goursat; Puiseux for Appell, and to some extent for Koenigs ; and Raffy for Darboux. For the examination of l'agrégation Andoyer, Hadamard, and Blutel are engaged in this kind of work.

\section{The Examinations.}

Perhaps this is the fittest place to state what the examinations for the licence, agrégation, and doctorat are. A young man who wishes to follow the career of mathematics naturally aims at a professorship in a university. To attain such a position he must pass the doctorate; to do this he must previously have passed the licence. Now positions at the universities are relatively few, and only the most talented can hope to reach them. On the other hand, the advance in the lycées to a larger salary is more rapid at the start than at the universities, and some who could rightfully aspire to a university career, are forced from pecuniary considerations to choose the lycée. The greater part of the students thus look to the lycées as their resting place for life. But to become professor in a lycée one must have passed the agrégation, which presupposes the licence. Let us then consider these three examinations as far as they concern us.

The Licence. Up to 1896 there were three sorts of licence, viz.: licence ès sciences mathématiques, licence ès sciences physiques, licence ès sciences naturelles. Since then the program has been changed. Besides the 9 mathematical subjects we mentioned above, the Faculté des sciences gives instruction in 9 more, chemistry, zoölogy, etc. A certificate of licence ès sciences without other qualification in the title, but with mention of the subjects passed on in the text of the diploma, is now given to any one who has passed examinations on 3 of these 18 subjects. The examinations on the different subjects are taken at will; each examination successfully passed entitles the student to a certificat for that subject. The examinations are written and oral. The written examinations consist of two parts, an épreuve écrite and an épreuve prâtique; each lasts about four hours. The first of these two written examinations is more theoretical and abstract, the second is generally a numerical example with extensive calculations. The oral examination is held before a jury of three professors and lasts 15-20 minutes.

Doctorat ès Sciences Mathématiques. There is no title of doctor of philosophy in France. As already mentioned, the 
German philosophical faculty is represented in France by the faculty of letters and the faculty of sciences. The first gives the title docteur ès lettres; the second faculty gives three titles, docteur ès sciences mathématiques, docteur ès sciences physiques, docteur ès sciences naturelles. We are, of course, interested only in the doctorate of mathematical sciences. This requires the licence ès sciences with mention of calcul différentiel et integral, mécanique rationelle, and a third certificate at the choice of the candidate. In addition a these is required, which must contain original discoveries or present the subject in an original manner. The size of these thèses averages 50-60 quarto pages, and their quality--so far as the University of Paris goes, and most of the mathematical doctorates are taken here-is considerably superior to that of the German dissertation.

Remark that the French desire to maintain the exclusiveness of the doctor title. For ten to fifteen years the quality of the thèses has been slowly rising, so that now only a small part of the German dissertations would be accepted at Paris. At the same time the thèses are written much more independently than is usual in Germany. It is not considered good form in Paris to consult the Professor for assistance. A student who is not independent enough to carry on his work without more than the slightest aid has very little chance of a university career.

Besides this thèse, there is a seconde thèse on a subject assigned by the faculty, which is generally one that the candidate has an interest in but which is not in the line of the principal thèse. There is no rigorosum in the German sense and no promotion at all. Everything turns on the principal thèse. If this contains sufficient original work it is admitted and permission given to publish it. Of late years no thèse has been accepted at Paris which has not been published. Although there is no rigorosum, there is still an oral examination. This is the soutenance publique of the two thèses. It is a very solemn affair, the examiners appearing in great state. As far as the principal thesis is concerned, it is a mere form. In regard to the second thesis it is really a mild kind of oral examination. The candidate is expected to have prepared the second subject sufficiently well to be able to answer benevolent questions.

The Agrégation. Unlike the baccalaureat, the licence, and the doctorate, the agrégation is a competitive examination. Each year the number of candidates who will be received is determined in advance by the minister of public instruction, in accordance with the needs of the lycées. For the sciences 
mathématiques it is at present about 7 or 8 eash year; the number of candidates is about 100. For the doctorate in mathematics we said the licence must mention 3 certificats; for the agrégation it must mention 4 -the extra certificate being the physique générale. Also the certificate at the option of the candidate must be in mathematics. Usually at Paris it is Darboux's course on higher geometry. The courses of Picard and Poincaré, being of very elevated nature, are chosen less frequently. To pass the agrégation the student usually spends at least three years, and as follows: Each of the first two years he employs in passing two of the four certificats. Having these off his hands, he turns his whole attention to preparing for the agrégation proper. This examination is the most severe that $I$ have any knowledge of, and is worthy of some detail. Remark first that it is an examination whose object is to choose among the candidates those best fitted to teach in the lycées. The examinations thus turn largely on the subjects there taught. They consist, as almost all examinations in France do, of two parts ; a written and an oral part. The first two written examinations take questions from subjects taught in the classe de mathématiques élémentaires and the elasse spéciale. The two following examinations which are based on the courses heard at the university are: $1^{\circ}$ Composition sur l'analyse et ses applications géométriques. This usually involves the theory of partial differential equations and differential geometry of space, $2^{\circ}$ Composition de mécanique rationelle. Each of these four examinations lasts 7 hours. The papers are the same for all France. Those that reach a sufficiently high standard are called admissible, and these, if living in the provinces, must go to Paris, where the final competition is held. Here the examinations consist of two parts. First, two new compositions and, secondly two leçons. The compositions consist of the solution of a problem in descriptive geometry, and the solution of a problem in analysis requiring numerical calculation. These two last each four hours. The two leçons treat of subjects taught in the classe élémentaire and classe spéciale and take place as follows: The candidate draws by lot one question among 25 . For the leçon on mathématiques élémentaires he has three hours, for the leçon on mathématiques spéciales four hours to think over how he will present the subject of the leçon. They have no books to assist them. They appear individually before the jury and give the leçons as if before a class in the lycée. The examinations last at most an hour each. Some unfortunates are cut down before they have talked ten minutes. 
We note the differences between the examination of the doctorate and agrégation. The first tests exclusively the originality of the candidate, the second his ability as a teacher in a lycée. The second is competitive, because it gives the successful candidate the right to demand a place as professor in a lycée ; the first is not, because it gives him no right to teach anywhere. Among the candidates who were admissible but not successful are chosen the chargés du cours and occupants of other inferior positions in the lycées.

\section{The Collège de France.}

This institution is independent of the university and has some 40 chairs, whose occupants are among the most distinguished savants of France. For us, only the four following chairs are of interest.

Mécanique analytique and céleste; Lévy (Hadamard, suppléant).

Mathématiques ; Jordan.

Physique générale and mathématique ; Bertrand (Deprez, suppléant).

Physique générale and expérimentale; Mascart.

The courses at the Collège de France are free to all ; any one can enter a lecture and leave it when he chooses. The audiences in some courses are very mixed. Retired petty merchants, and amiable old ladies who seek a small diversion at no expense are not infrequent visitors. Many of these promptly begin to nod. They cannot well fall quite asleep, as the authorities have taken care to provide benches without backs. Even for those who have no desire to slumber, this is a serious discomfort. For the first time in my life I experienced how painful it is to sit an hour with nothing in front or behind to rest against. Fortunately for us mathematicians, our subjects are too esoteric to attract this kind of audience. The duties of the professors I have mentioned are simply to lecture. They do not come in contact with the student by directing his work or subjecting it to examination. All attendance is voluntary and no official recognition is given for it. Where these chairs are held by strong and enthusiastic men, the lectures given at the Collège de France can become sources of the highest inspiration.

\section{The École Normale Supérieure.}

The object of this school is to form the future professors of the lycées and universities, by supplementing the instruction they receive at the Sorbonne and the Collège de 
France. As at the École Polytechnique, its élèves live at the school as internes. The École falls into two distinct departments, science and letters. Only the first interests us. The present year 166 candidates presented themselves for admission to the department of science; only 13 can be received yearly. Of these generally from 7 to 9 intend to study the mathematical sciences. The élèves in mathematics spend three years at the school preparing for the agrégation. The plan of study is as follows: During the first year they usually attend Goursat's course at the Sorbonne on the calculus and Lippmann's and Bouty's course on physics, taking at the end of the year the examinations for these two certificates. At the École, during this year, they attend each week a conference by Tannery and one by either Painlevé or Borel. These last each an hour and a half. They are like the conferences given at the Sorbonne, elucidating the topics the élèves have heard there and exercising them in the solution of problems. Problems are given also to the élèves to work out of class and these are then criticised by the professor before the whole class. In the second year the two remaining certificates are taken, viz. the mécanique rationelle by Appell and usually the géométrie supérieure by Darboux. For the first of these Painlevé gives conferences at the École; for the second, Raffy. During the third year the élèves attend what courses they choose at the Sorbonne or the Collège de France. At the École they are drilled in giving leçons preparatory to the agrégation : on algebra by Tannery, on analytic geometry by Borel, on analysis by Painlevé. Élèves of the second and third year also hear courses of an advanced nature given by Painlevé and Borel. Last year they were on the theory of differential equations and ensembles, subjects to which these young savants have made important contributions.

The training the élèves receive at this school is thus a happy mixture of theory and practice. To judge of its efficacy I have only to remark that of the 100 candidates in mathematics at the agrégation 7 or 8 are Normaliens. Of the 7 or 8 who succeed in this terrific competition, all but one or two are again Normaliens.

Let me add that I should do these élèves a grave injustice if I left the impression on the reader that their efforts are bent exclusively to preparing for their examinations. Many of them find time to make extensive studies and researches, often the commencement of a doctor's thèse, in regions remote from their examinations. 
A few words on the life at the École. The building itself makes the impression of a fine old palace in renaissance style, with beautiful court yard, fountain, trees, flower beds. Around its walls are busts of distinguished savants and anciens élèves. Instruction and pension are gratuitous for those who afterwards teach. The life at the school must be very pleasant and profitable. Living and studying here together for three years, surrounded by a quiet and studious atmosphere rendered more effective by the distinguished past of the school, subject to the stimulating influence of a generous rivalry among themselves, and enjoying daily and intimate intercourse with their professors, the-e élèves, the pick of France, certainly have ideal opportunities to unfold their latent talents. The genius of the place as far as mathematics is concerned is the directeur des études scientifiques, M. Tannery. The affectionate respect and gratitude which the élèves cherish for him long after leaving the school is very touching. If we seek the two men whose influence has been most inspiringly and profoundly felt by the present younger generation of mathematicians in France we certainly would mention without hesitation Hermite and Jules Tannery. It is a pleasure to note that the privileges of this celebrated place of learning are open to American students, either in part or even as internes. In the latter case the pension would be 1200 francs a year. For a student of limited means, but of distinguished talents, this is an opportunity of great value.

\section{The École Polytechnique.}

Until recent years, this school was famous not only for the great engineers it produced but also for its brilliant mathematicians. Cauchy, Poncelet, Lamé, Liouville, Chasles, Serret, Halphen, Laguerre, Jordan, Hermite, and Poincaré, not to mention a host of other celebrated mathematicians, were all trained here. But the demands made on an engineer to-day are so great that it is impossible to give the élèves more than a glimpse of modern mathematics. The spirit of the place has changed in accordance with this fact. An élève who has mathematical tastes on entering finds them discouraged rather than encouraged by his stay at this school. Instead then, of being a great breeding place for mathematicians, as it was during the first half of this century, it has now sunk into insignificance in this respect. I should not devote much space to this school, therefore, if it were not that it still exercises on the élite of the French 
youth a truly remarkable fascination, which produces this curious and as it seems to me unfortunate change in the destinies of so many of the young men we have been following. We have seen namely that the élèves of the classe de mathématiques spéciales who propose to follow a mathematical career present themselves not only at the École Normale but also at the École Polytechnique. Those who succeed at the École Normale become mathematicians, the remainder have their plans of life changed completely, for statistics show that, only an insignificant per cent. of the élèves of the École Polytechnique follow the mathematical career. Observe too that since only 7 or 8 can possibly enter the École Normale, by far the larger part of the successful candidates of each year must needs enter the École Polytechnique. The result of this system, so it seems to me, is that France loses many a good mathematician and receives in lieu a relatively poor engineer or officer.

The élèves remain at the school only two years. Instruction in mathematics is given during both these years, but not continuously. During $3-3 \frac{1}{2}$ months each year, the élèves have 3 lectures a week each lasting $1 \frac{1}{2}$ hours. The professors are Jordan and Humbert. The lectures are supplemented by répétiteurs who are often mathematicians of high distinction. At the present moment we find here Appell, Goursat, Koenigs, and Painlevé. At the same time I must add however that the practical drill the élèves receive is inferior to that given at the Sorbonne,not to mention the École Normale where it reaches its highest excellence.

We have seen how strong the attraction is which these two Écoles exercise on the French youth; that instead of entering the university on passing the baccalauréat as is done elsewhere, they seek to enter these schools. The reason for this is not difficult to find. In France the struggle for existence is severe. The École Polytechnique offers all its graduates a career which is at once rapid, brilliant, and certain. The École Normale assures its graduates at least a professorship in a lycée and prepares its élèves for this or for a university career better and more rapidly than the university can do it

Closing Remarks on the French System of Mathematical Instruction.

Before leaving the subject of mathematical instruction let me note the difference between the attitude of mind of the French and the German student while preparing for his career as a mathematician. The German university re- 
quires 8 semesters to prepare for the doctorate. As there are no examinations till the close, the German student is free to roam about not only in mathematics but in physics, philosophy, history, etc. In fact a part of the rigorosum requires a knowledge of philosophic studies. At the close, the examinations, which are oral, aim not so much at specific encyclopedic knowledge as a largeness of view and maturity of judgment. As we Americans have so often heard at Commers, Frei ist der Bursch! In France, on the other hand, from the moment the élève leaves the classe de rhétorique, i. e., from 16 years onward, he has an examination before him at every turn. The plans of his studies are very largely marked out for him; care is constantly taken to see he makes no lost steps and that he is properly prepared to pass his examinations. The university and the Ecole Normale make the impression of a great institution wonderfully arranged to turn out a certain product, in a certain amount, in a certain degree of excellence, with the least loss of time and energy. The Collège de France is the only seat of learning which reminds us of the German university, both in regard to its indifference whether the seeds scattered abroad with lavish hand bring forth fruit, and in respect to the liberty of its professors to teach what they choose and of the student to learn what he will. While making objectively these observations I wish to refrain from passing any judgment as to which scheme is the better. Indeed, can we rightfully say more than that each seems best adapted to the needs and temperament of its people? Remark finally that there is to-day a tendency in Germany in official circles to restrict the Lern- und Lehr-Freiheit, however one may be unwilling to confess it. On the other hand strenuous efforts are being made in France to increase the number of cours libres which shall be quite independent of the demands of any examination.

\section{CAREer.}

We have seen how France trains its mathematicians. The question we now ask is, what are the inducements it offers young men to follow this career? This question is one of no mean importance if we are looking for the causes which make a country eminent for the steady growth in volume and quality of its output in a science. Because, if the career is slow and arduous, if it offers slight chances of reward in comparison with other professions or with commerce, it is evident that many of the best minds will be dis- 
couraged from entering it. This question has also its lesson for us. If we wish American mathematics to take a place alongside that of France, Germany, and Italy, we mustlook to it that the conditions under which the American mathematician has to work compare favorably with those which surround his colleague abroad.

We observe in the first place that the position of a young doctor in mathematics is much better in France than in Germany. In Germany the young Privat-docent may be 28 or 30 before receiving an ausserordentliche Professur. Until this time his salary is practically nothing. In France the young doctor who is Agrégé may enter a lycée as professor in mathematics, if no place as maître de conférences in a university is available. Here the lowest salary for Paris is 5,500 francs, the highest 9,000. Promotion takes place, $1^{\circ}$ by choice, $2^{\circ}$ according to time in the service. From the sixth, $i$. e., the lowest class in rank, to the third the number of those that can be advanced each year by choice is equal to that of those that are advanced by ancienneté. For the second and first classes, two advancements can be made by choice to one by ancienneté. Advance of those hors classe (a vanishing number) is exclusively by choice. The advancements are made December 31 each year, and take place so that there are always 20 per cent. in the sixth class and respectively $18,18,16,14,14$ per cent. in the others. The advantage of this scheme is obvious. It leaves plenty of room to encourage unusual talent to exert itself ; at the same time it does not dishearten the others from doing their duty with enthusiasm. The chargés du cours, i. e., those who did not succeed in the agrégation receive from 2,800 to 4,800 francs. The number of hours a professor has to teach in a lycée varies from 12 to 14 a week. The remainder of the time is strictly his own.

The majority of young doctors of promise prefer not to avail themselves of the lycées, and generally it is not long that they have to wait for a position as maître de conférences at a university. At Paris the salary for such a position ranges from 5000 to 7000 francs. For this the incumbent gives two conferences a week, each lasting $1 \frac{1}{2}$ hours. This may well seem munificent; for he not only has abundant time to carry on his own researches but has also ample means to live well. It often happens that a young man occupies other positions, as an examinateur, or répétiteur, or suppleant at one of the numerous other institutions of learning at Paris.

At the age of 30 a young maître de conférences may be 
made professeur. This however rarely happens now. The number of chairs is not large and promotion is not rapid by any means. This is offset by the relatively large salaries and by the fact that the occupants are often active in other capacities, as just mentioned. In Paris the salary of a professor is from 12000 to 15000 francs. In the provinces it varies from 6000 to 11000 . The professor is expected to give but one course of lectures, viz., the course his chair calls for. These take place twice a week and last from one to one and one-half hours. Those courses, which are repeated each year, require but little preparation and hence but little labor. On the other hand the stimulating effect which is exercised on the mind of the professor when lecturing on subjects which are interesting him is altogether wanting. The number of hours a professor has to lecture seems to us magnificently small. Even in Germany it is not strange to see an ordentlicher Professor lecture 6 hours a week and even have in addition 2 hours Seminarübungen. Let me give here for comparison the salaries German professors receive. In Berlin these are: Professor ordinarius, 5700 Marks and 100 Marks increase each four years, till after 24 years the maximum salary of 8100 Marks is reached; Professor extraordinarius 3300 Marks with additions as before till a maximum of 5700 Marks is attained.

In other Prussian universities the salaries are respectively for full professor 4000 to 6000 Marks ; for assistant professor 2000 to 4000 Marks. In addition there is here a Wohnungsgeldzuschuss, which varies from case to case, but which may roughly be put at 500 Marks.

One feature of the life of a French university professor is certainly very disagreeable and wearisome; we mean the great number of examinations he is obliged to hold. In the last report of the Doyen of the Faculté des sciences at Paris, we read that its professors attended 9,946 examinations. Of these, 8,485 were those for the baccalauréat. From July 1 to August 15, and November 1-10, the time of the professor is more or less broken into. To indicate roughly the extent, I would say that on an average a professor may expect to be called on to assist at 12 examinations of baccalauréat, which consume, taking into account the time spent in marking the compositions, five hours each. Besides this, one may calculate on 20 examinations for certificates, of one hour each. In all 80 hours.

In spite of these losses, I think the French professor has much more leisure for research and publication than his German colleague. At any rate, we Americans have a les- 
son to learn. How many of our professors have from 10 to 12 hours a week to teach, besides faculty meetings, committee meetings, and examinations in harassing multitude! At the present moment our universities for the first two years are gymnasia or lycées, and our professors are tied down to a régime which is proper to secondary instruction. At the same time most of us are expected to be conversant with the latest phases of our science and to advance it by our own researches. This anomalous state of affairs is certainly transitional. Some way, the problem must be solved how to retain all the excellencies of our college life, which in my mind is one of the pearls of our American civilization, and at the same time create an environment for certain men of talent which is conducive to the highest scientific activity.

II.

\section{The American Student of Mathematics at Paris.}

In sketching the instruction given in mathematics at the Sorbonne, the Collège de France, and the École Normale, I have indicated at the same time what the American student may get here. I wish now to give more specific information on certain points. What are exactly the advantages and attractions which might induce an American to study in Paris?

To begin with, there is Paris and the French people themselves. To live in Paris as a serious student is an education in itself. There is, in the first place, the wealth of historic associations. Paris is saturated with the spirit of bygone days which to the attentive and loving eye is manifest on every side. Its galleries, churches, palaces, public squares, the Seine, St. Cloud, Versailles, Fontainebleau cause many a page of history to flash out before the mind's eye with startling vividness. Then there is the spirit of the language to learn, and the customs and points of view of those that use it. Some insight gained in this respect, French literature takes on new meanings and presents fresh beauties. But it is impossible to go into detail here ; the Théâtre-Français, the Opéra, the Salon, its fêtes and exhibitions, a hundred influences are constantly at work to refine and educate if one is so disposed.

Turn now to the mathematical side. An American student who intends to spend a year here, and since the courses run with a few exceptions through the whole year it is advisable to calculate on at least a year, will do well to come to Paris as early as possible in June. As the lectures close here 
from the 10th to the 15 th of June, he cannot count on hearing anything at this stage ; the examinations however keep the university open until well into August and many of the professors are still in town. He can thus look around and prepare for autumn. If he has no friends here, he will do well to visit the bureau of the Comite de patronage des étudiants étrangers, directed by the university. Here he will find some one who talks English and who will give him valuable information regarding the university, lodgings, etc. There are several clubs which he can join, and at this bureau he can get letters of introduction to them. I mention the Club Americain, the Cercle des étudiants protestants, the Association générale des étudiants. In these places he will be well received, will soon get acquainted and begin to feel at home.

Many students will prefer not to stay in Paris after this first orientation. The weather is very hot and life is not pleasant or healthful here in the summer months. It will be well, then, to go to a university town like Grenoble or Geneva. Here the Alps are at one's very door and the excursions they offer are without end. Generally speaking the American student, while able to read French fluently, cannot speak it or understand it well when spoken. The summer should be devoted to acquiring proficiency in this respect. At Grenoble and Geneva as well as at Paris, summer courses are given under high auspices and by professors of the university and lycées on French language, literature, art and history, supplemented by practical exercises of a most valuable kind. These should be frequented. The fees are insignificant.

The university opens November $3 d$; it is well to return some time before to engage lodgings. Here two courses are open to the American; either he can engage rooms in a hôtel meublé or take pension. The latter seems preferable. The habit in Germany of obtaining rooms or pension in private families who have one or two chambers to let is not usual in the quarter about the Sorbonne. Rooms can be had from 30 franes a month up. It is well, however, to count on paying from 40 to 50 . Good pension, room and board, can be had for 200 francs a month. The prices, we observe, are a little higher than in Berlin. Still, on 600 or 700 dollars a year a student can live nicely in Paris, spending the summers elsewhere.

The formality of matriculation is quite as simple as in Germany. It is well to bring a passport and the diploma received at college. If one wishes to take his doctorate in 
mathematics here, he has an advantage not procurable at the German universities; for, as already observed, no Latin or Greek is necessary for this. In regard to the courses he will wish to take; this to be sure depends on what he has already had. It is safe to say he will want to take, at the Sorbonne the courses of Darboux, Poincaré, and Picard; at the Collège de France, those of Jordan and Hadamard; at the École Normale those of Tannery, Painlevé, and Borel. The courses at the Collège de France being altogether public, there is no formality of inscription. To attend courses at the École Normale it suffices to present oneself to M. Tannery. Besides these cours magistraux, the American student will derive exceptional benefit from taking part in the conferences (Seminarübungen) directed by Puiseux, Andoyer, Raffy, and Hadamard at the Sorbonne, and by Tannery, Painlevé, and Borel at the École Normale. At the start he will find himself very inferior to his French comrades, as is natural when we consider how long they have been trained in this rude exercise. But in my estimation, this training is of utmost value. It is, perhaps, the most characteristic feature of the French system and should not under any circumstances be neglected.

Besides these courses in mathematics there are numerous courses in mathematical physics and allied subjects which I have not room to mention. Finally, I must call attention to the cour'ses on history, philosophy, literature, etc., given in the Faculté des lettres by some of France's most distinguished savants. To attend these lectures it is necessary to be inscribed in this faculté ; but this is a mere form and involves no additional expense.

I come now to the last point, but also a most essential one. How is an American student to obtain the doctorate. At present there are two: the doctorat de l'État and the doctorat de l' Universitê de Paris. The first has always been available, the second was created in 1898 by virtue of a law passed the year before, authorizing all universities to create a university doctorate. I believe only Paris has availed itself of this privilege up to the present. Consider the requirements for the doctorat de l'État. In the first place, the American student must have a B.A. or a B.S. to offer as an equivalent of the baccalauréat. To have this accepted, special permission, which will always be granted to a worthy candidate, must be obtained from the minister of public instruction. Next he must pass the licence with mention of calculus, mechanics, and a third certificate at will. To pass these three examinations the American student will find it 
necessary to frequent with assiduity the conferences, in order to acquire the dexterity necessary to solve the searching questions of these written examinations. Finally, there are the two theses already mentioned. As observed above, the principal thesis is ordinarily worked out quite independently by French students. For American students this is not necessary. They will find the professors under whom their work falls quite as ready to talk it over with them and to offer suggestions as in Germany.

Turn now to the doctorate of the university. Here the conditions are the same, except that two instead of three certificates are required. There is no question that the ordinary American student who takes his doctorate in two years in Germany could satisfy the requirements for the doctorate of the university of Paris in the same time; and as to their value as testimonials of work accomplished, I see no difference.

In closing this article I wish to express my thanks to all the gentlemen, too numerous to mention here, who by their courteous and kind attentions assisted me in procuring the materials for it. My gratitude is due in a particular measure to M. Paul Painlevé.

PARIS, July, 1899.

\section{APPLIED MATHEMATICS.}

Cinématique et Mécanismes, Potentiel et Mécanique des Fluides. Cours professé à la Sorbonne. Par H. Poincaré. Paris, Carré et Naud, 1899.385 pp.

THE certificates granted at the Sorbonne for proficiency in mechanics require the study of a certain programme of subjects-amongst others, those on the title page of this volume. The somewhat curious mixture is probably accounted for by the fact that the students who attend these lectures desire to obtain only a certain degree of information and that in as short a time as possible. To treat four subjects in applied mathematics, within the compass of a single volume is of course impossible, if an adequate account of each is to be given. Nevertheless, M. Poincaré has, on the whole, succeeded in setting forth the main ideas of all of them, and his treatise thoroughly studied will probably fulfil the purpose which it is intended to serve. 